\title{
CAMBIOS EN LAS CONCENTRACIONES DE HIERRO Y CINC EN LECHE DE BÚFALA MURRAH DURANTE LOS PRIMEROS 105 DÍAS DE LA LACTANCIA
}

\author{
Beldomenico, H. R. ${ }^{1}$, Campagnoli, D. U. ${ }^{1}$, \\ LisoWyJ, P. C. ${ }^{1}$, TSChOPP, J. ${ }^{2}$ \& Althaus, R. L. ${ }^{2}$
}

\begin{abstract}
RESUMEN
Los oligoelementos, preferentemente hierro, cinc, cobre y manganeso, presentan una gran importancia desde el punto de vista metabólico, además de cumplir funciones esenciales en el organismo, ya que actúan como cofactores de numerosos sistemas biológicos enzimáticos.

Considerando el rol que desempeñan estos microminerales en la nutrición humana y tendiendo a lograr la utilización íntegra de la leche de búfala, se planteó como objetivo determinar las concentraciones de hierro y cinc en leche de búfala de raza Murrah en diferentes momentos del período de lactancia, a fin de evaluar la calidad en estos oligoelementos.

Los niveles de hierro y cinc se determinaron por espectrosocopía de absoración atómica en las cenizas secas de 72 muestras de leche de búfalas de raza Murrah procedentes de la provincia de Santa Fe, Argentina. Las concentraciones medias de hierro y cinc fueron $0,37 \pm 0,01 \mathrm{mg} / \mathrm{l}$ y $5,07 \pm$ $0,71 \mathrm{mg} / \mathrm{l}$, respectivamente. Se observaron disminuciones significativas $(\mathrm{p}<0.05)$ en los niveles de hierro (45 días del período de lactancia) y cinc (60 días del período de lactancia).

Los valores de cinc durante los diferentes momentos de la lactancia resultan suficientes para cubrir los requerimientos nutricionales de los lactantes, mientras que el hierro, por estar presente en baja concentración necesita de una suplementación adicional.

Palabras clave: hierro, cinc, leche, búfala, estado de lactancia.
\end{abstract}

1.- Laboratorio Central. Facultad de Ingeniería Química, Universidad Nacional del Litoral. Santiago del Estero 2829. (3000) Santa Fe.

2.- Departamento de Ciencias Básicas. Facultad de Ciencias Veterinarias, Universidad Nacional del Litoral. Kreder 2805. (3080) Esperanza, provincia de Santa Fe.

Manuscrito recibido el 12 de noviembre de 2001 y aceptado para su publicación el 2 de diciembre de 2002. 


\section{SUMMARY}

\section{Nutritional levels of iron and zinc in Murrah buffalo milk: effect of the lac- tation periode.}

Mineral nutrients (prevalently iron, zinc, copper, manganese) have a relevant behavior in metabolism and other body essential functions, as they actuates as enzyme cofactors in numerous biologic enzymatic systems.

Considering the important role of those trace elements in human nutrition and searching for a integral profitable utilization of buffalo milk, the objective of our work was to determine iron and zinc concentrations in Murrah buffalo milk, in different stages of the lactation period, in order to conclude, about it mineral nutrient quality.

Dry ash of samples and atomic absorption spectrophotometry determination for iron and zinc were made in 72 whole milk samples from buffaloes breeded in Santa Fe Province, Argentina. Mean iron and zinc concentrations found were $0,37 \pm 0,01 \mathrm{mg} / 1$ and 5,07 $\pm 0,71 \mathrm{mg} / 1$, respectively. Significative decreasing $(\mathrm{p}<0.05)$ in iron levels (45 days lactation period) and in zinc levels $(60$ days lactation period) were observed.

Milk during the different stages of the lactation present in all cases zinc concentrations that satisfies the nutritional requirements of the children, meanwhile iron, that is present in low concentrations, do not fully cover the necessary iron intake, leading to the need of additional supplementation to satisfy nutritional requirements.

Key words: iron, zinc, buffalo, milk, lactation period. 